\title{
Modernization Models of the Second Half of the XX Century in a Comparative Historical Dimension
}

\author{
Tatiana Suzdaleva \\ Bauman Moscow State Technical University \\ 5/1 2d Baumanskaya St. \\ Moscow, Russia 105005 \\ E-mail: syzdalev@ list.ru
}

\author{
Konstantin Fedorov \\ Bauman Moscow State Technical University \\ 5/1 2d Baumanskaya St. \\ Moscow, Russia 105005 \\ E-mail: fedorov@live.ru
}

\begin{abstract}
The basic models of modernization in the second half of the XX century are considered. The main attention is paid to the analysis of the achievements and contradictions of the "catching-up" model of modernization adopted by the countries of East and South-East Asia. On the basis of a comparative historical analysis it was concluded that it is possible to use the experience of these countries in modernizing modern Russia.
\end{abstract}

Keywords-modernization; "organic model"; "catching-up model"; the role of the state, society; "new industrial countries"

\section{INTRODUCTION}

Modernization in modern social and humanitarian sense is understood as a systemrenewal of society, its transition to a higher development stage. The formulation of the modernization concept in the Western historiography was caused by the need to explain the economic and sociopolitical processes that took place in the world under the influence of the scientific and technological revolution of the second half of the XX century. The pioneers of the modernization theory in the 1950s-1960s in the USA and Great Britain were the economist W. Rostow, sociologists T. Parsons and E. Shils, R. Dahrendorf, politologist L. Pye [1].

The upcoming society and transition to it is differently described by Western authors. Z. Brzezinski called it "a technotronic era", D. Bell introduced the term "a postindustrial society", A.Toffler coined "a superindustrial society". In the early 1960s F. Mahloop and T. Umesao introduced the term "information society". Parsons stated that the transition to a new development stage results from three revolutions: industrial, democratic and educational ones, which in his opinion were the main motive forces of the civilization growth [2]. According to A. Toffler, modernization is not limited by economic growth, "it carries new family relationships; other ways of working, loving and living; new economics; new political conflicts, and beyond all this - an altered state of consciousness" [3]. However, despite the terminology differences, the acknowledgement of the key role of technological revolutions in civilization development unites the modernization theory supporters.

Life forced theorists to correct their conclusions. In the second half of the XX century there were different options of overcoming economic backwardness. In the 1960sthey started talking about the West German and Japanese "economic miracle". Later this term was extended to Singapore, Taiwan, South Korea, Chile and other countries. National modernization models had their own features (historic, cultural, religious traditions, participation of small and medium business, etc.) However, it did not prevent many Western scholars (W. Rostow, M. Loewy, D. Lerner and others) from considering modernization in developing countries exclusively as westernization, i.e. copying the Western development model and way of life. Traditional institutions and values in this approach were seen as an obstacle to modernization [4].

In Russia the growing interest in modernization theory was closely related to economic reforms of the1990s. At first, domestic authors were guided by the works of Western economists, sociologists and culturologists. It is not surprising that at that time modernization was mainly interpreted within the framework of the linear model, as a transition from a traditional to a modern society of the Western type. However, due to its unhistorical nature and West centrism such an approach proved incapable of explaining the diversity of modernization processes in different countries of the world. Now in books and articles of domestic authors the foreign experience of modernization is viewed through the prism of Russian realities. Close attention is paid to the civilization features of the countries that have taken the path to modernization, the influence of historical and cultural traditions on the choice of their development vector $[5,6,7,8]$.

The purpose of this article is to study modernization models in various countries in the second half of the XX century using the method of comparative historical analysis.

\section{II. "ORGANIC" AND "CATCHING-UP" MODERNIZATION MODELS}

According to S.A. Gavrov, modernization processes should be studied in three dimensions. Firstly, as the internal development of countries in Western Europe and North America referring to the New time; secondly, as "catchingup" modernization characteristic of countries not belonging to the first group but aspiring to catch up with them; and thirdly, as modern innovative processes characteristic of 
countries of Western civilization [9]. In our opinion, in regard to the second half of the XX century it is more appropriate to speak about "organic" and "catching-up" modernization models. "Organic" modernization is typical of developed countries of "old capitalism" with a market economy and stable democratic political regimes. This modernization model is of systematic nature and complexity. But the implementation of "organic modernization" requires a high level of maturity of the prerequisites in all spheres. The renewal of economic and social structures takes place "from below" with the active participation of civil society.

The goal of "catching-up" modernization is to overcome in a short time economic backwardness. The meaning of the term is revealed in the name of the book "From the Third World to the First one" written by the "father" of Singapore's economic miracle Lee Kuan Yew. "Catchingup" modernization is usually carried out by the state "from above" by authoritarian methods [10]. Consequently, one of the main differences between "catching-up" modernization and "organic" one is the key role of the state.

Western scientists usually advertise the Western (liberal) modernization model as the most effective one and almost as the only acceptable under present-day conditions. Examples of the PRC, South Korea, Taiwan, and other countries of East and South-East Asia that have overcome economic and technological backwardness from the West within the framework of the "catching-up" modernization refute this view. Therefore, now in the scientific community there is a retreat from simplified schemes, the acknowledgement of diversity of modernization processes, the rejection of the modernization image as a simple replacement of traditional values by liberal institutions.

Thus, there is no universal modernization model. The experience of each country that has gone through the process of the stage transition needs to be thoroughly studied. Beyond the historical context, all the arguments about the ineffectiveness of this or that option of modernization are unscientific in nature [11]. Only a comprehensive analysis of the historical conditions in which a particular country pursued a policy of reform provides you with an objective assessment of its acquisitions and losses.

Moreover, the experience of modernization reforms in highly developed countries is of limited importance for Russia since it lacks many economic and socio-cultural prerequisites that have been formed in the West over the centuries. The most relevant for Russia is the experience of the new industrial countries of East and South-East Asia, which having taken the path of "catching-up" modernization managed to completely or partially overcome their peripheral position[12, 13].

\section{MODERNIZATION VECTORS OF THE EAST AND SOUTHEAST ASIA COUNTRIES}

Japan was the first of the Asian countries that took the path of modernization after the Second World War. One can enumerate the factors of the Japanese "economic miracle" for a long time. But the main role in the transformation of the Land of the Rising Sun was played by the reforms carried out in the defeated country under the auspices of the United States and the correctly chosen state development strategy. Within the framework of this strategy, selective support of the most promising industries was provided. Japan has relied on imports of technologies and licenses, not goods. The main sources of foreign patents and licenses were the USA $(65 \%)$ and the countries of Western Europe (about 35\%). The state provided protection from foreign competitors. All these measures together have led to impressive results. In the early 1980's Japan's share in world exports of high technology reached 25\%. Rapid economic and scientific and technological progress was accompanied by an increase in the standard of living. In 1987 Japan surpassed the US GDP per capita. The goals set by the country after the defeat in the Second World War were achieved [14].

The example of Japan had a great influence on the socalled "new industrial countries" of the first wave such as Taiwan, South Korea, Singapore and Hong Kong that entered the stage of forced economic growth in the 1960s. However, under the changed conditions, simply copying the Japanese experience could no longer guarantee success. An essential condition for the economic progress of the new industrial countries was effective public and corporate management. It was the presence of political will and capable state machine that allowed creating an effective system of interaction between the public and private sectors. According to Russian economists, despite the existing differences and the liberalization of political regimes in some Asian countries that emerged at the end of the XX century, the state in Asian countries retains the role of the organizer of social and economic development, the defender of the domestic market, the business incubator, the infrastructure builder, the regulator of relations between the national and foreign capital.

For example, seven five-year plans were successfully implemented in South Korea from 1962 to 1996. The planned system of the economy, especially in the 1960s and 1970s, first laid the foundation for the country's development and, secondly, made it possible to build a clear model of economic relations, create an optimal structure of economic and organizational ties. Average annual GDP growth in 1961-1970 in the Republic of Korea was 8, 9\%, in 1971-1980 - 8, 5\%, in Taiwan - 8, 6\% and 9, 3\% respectively. As a result, per capita GDP which in these countries was approximately at the level of sub-Saharan African countries in 1960, increased almost 15 times in the Republic of Korea by the year 2000, in Taiwan - more than 20 times [15].

In the process of modernization, the economy was restructured. In 1970 agriculture was the largest employer in South Korea $-30 \%$ of population worked there. After the war, $85 \%$ of the population of South Korea remained peasants. Today rural residents make up no more than 10$12 \%$ of the population.

The new industrial countries, named "Asian tigers" for the active foreign trade expansion, quickly conquered foreign markets. This was promoted by the policy of protectionism. Their governments subsidized the export of their industrial 
products. The protectionism policy made it possible to ensure the following result: if in 1960 the share of exports to South Korea's GDP was only 3,4\%, and Taiwan's - 11,6\%, then by 1980 these indexes reached $30 \%$ and $46,8 \%$, respectively [16].

It is generally recognized that one of the main factors contributing to rapid economic growth and high competitiveness of goods produced in Southeast Asia was cheap labor. In the first 8 to 10 years of modernization in South Korea and Taiwan, the average income of the population did not grow. But then the situation began to change for the better. The ruling elites and large corporations realized that overcoming poverty and equalizing incomes of the population is the most important condition for the economic growth. The growth of population incomes leads to an increase in mass consumer demand. This pattern was confirmed by Japan and the new industrial countries.

However, the success of Japan and new industrial countries is explained not only by economic factors. Asian modernizers made the best use of their national traditions, cultural values and mental features [17]. The primary importance was attached to Confucian ethics which is based on discipline, unquestioning obedience to the elders, dedication to work. Confucianism elevates labor to a high ethical category. "Do not worry that you do not hold a high post, worry about whether you are serving well in your place" - says one of the commandments of Confucius. "Asian tigers" were brought together by the fact that modernization was carried out under the conditions of authoritarian political regimes. In order to maintain stability, the activity of political parties and even of the parliamentary opposition was limited. Largely due to the firm forms of government, such multinational countries of Southeast Asia as Indonesia, Malaysia and Singapore managed to avoid ethnic bloodshed. Moreover, political stability and the absence of strikes in these countries appealed to foreign investors [18].

Later, and under other conditions, the second wave of modernization began in the countries of the Southeast Asia: Thailand, Malaysia, the Philippines, and Indonesia. The pace of their development was lower than that in the countries of the first wave, but they were stable. Elites of Southeast countries could use the experience of Japan and "the four tigers". In addition, foreign investors have already realized that investments in East Asia are very promising. By the mid-1990s the achievements of East and South-East Asia looked impressive. Average annual GDP growth in 19512000 in Thailand was $6,2 \%$, in the Philippines $-4,9 \%$, in Indonesia $-4,4 \%$ [19].

But the most striking example of modernization in the late XX - early XI centuries was demonstrated by China. Over the past three decades, in 1978 when the Chinese government headed by Deng Xiaoping declared a policy of building "socialism with Chinese peculiarities", the PRC showed very high rates of economic growth - about $10 \%$ per year. As a result, by the beginning of the XX century China's GDP had grown 8 times. China became the largest exporter, and it, as once the UK, can be called a "workshop of the world". In 2010, according to the volume of nominal GDP, the PRC took the second place in the world, and in 2014 it outstripped USA in GDP PPP, calculated at purchasing power parity. Since 1978, every 9 years, the real incomes of the Chinese have grown by $7,7 \%$ annually and by the beginning of the XX century have grown six-fold [20].

However, the uniqueness of the Chinese reforms is expressed not only in economic indexes. The innovation of Chinese modernization lies in the fact that it promotes Chinese development projects which gives grounds to speak about an "alternative model of modernity", i.e. the desire to create its own model and spread it throughout the world [21].

Undoubtedly, one should not idealize "the Asian model" of modernization. Authoritarianism at a certain stage exhausts the opportunities for growth and turns into an obstacle to the development of the economy. In addition, social problems are inevitably aggravated. It was these factors that caused a strong mass protest in South Korea in the mid-1980s which turned into a nationwide uprising. As a result, for the first time in the post-war history, the president of the Republic of Korea was elected democratically. It is significant that the 1993 government program "Internationalization Strategy for a New Economy" set goals not only to expand foreign investment, but also to limit administrative control and state interference in the economic life of the country [22].

The historical destinies of the countries in question are different. Many of them, as already mentioned above have gone through the stage of authoritarian political regimes. However, the very logic of economic changes requires the formation of appropriate political institutions that would allow thegrass-roots initiators of economic activity to realize their political interests. Strengthening this trend is incompatible with authoritarianism and, therefore, limits the time frame for the existence of the authoritarian regime demanding, as a result, its democratization. The diversification of the structure of economic needs multiplies the sources of the economic initiative "from below". The latter circumstance stipulates that with the growing diversity in the field of entrepreneurship, an ever more diversified structure of political needs is emerging, which cannot be met within the framework of authoritarianism. In addition, authoritarianism does not ensure an automatic development the latter requires an effective management.

\section{CONCLUSION}

The experience of modernization of East and South-East Asia, if properly used, is extremely relevant for modern Russia. What are the main lessons of modernization reforms within the framework of the "catching-up" modernization model?

Firstly, it is the active role of the state, which compensated for the immaturity of the economic prerequisites for modernization, the weakness or total absence of a business class. Moreover, the lower the starting level of modernization, the higher the role of the state was. This is the law of all "catching-up" modernization models. 
Secondly, the "catching-up" modernization was usually accompanied by the establishment of authoritarian regimes that pursued a policy aimed at creating new branches of the economy, introducing high technologies into production, providing training for skilled labor, creating modern education and research systems. However, authoritarianism should not be identified with repression. "Coercion to progress" relied on social consensus. The upper bourgeoisie counting upon tax breaks and state support, directed investments to the advanced branches of the economy. Other sectors of society were ready to sacrifice democratic freedoms in exchange for the growth of material well-being and for the expansion of prospects associated with the activation of vertical social mobility [23].

Thirdly, the experience of modernizing the new industrial countries shows an exceptional role in the transformation of national leaders. "The architect of Chinese reforms" Deng Xiaoping, the Prime Minister of Singapore in 1959-1990 Lee Kuan Yew, President of Taiwan in 1978-1988, Chiang Ching-Kuo, South Korean dictator Chung-hee Park were ambiguous personalities. But they were able to lead their countries out of backwardness and poverty to a fundamentally different level of development.

Next, the facts prove the inconsistency of a purely technocratic approach to the choice of modernization strategy. Blind copying of Western samples creates a threat of national identity loss, strengthens resistance to reforms. Therefore, the vital need is to find a balance between traditional values and the renewal of society [24]. Knowledge of the socio-cultural features of the inhabitants of a given territory, taking into account the factors of sociocultural diversity, allows "fine-tuning" of the reforms, developing non-standard institutional solutions designed to overcome "institutional traps" and bring the economy to a stable trajectory of development [25].

Finally, it must be borne in mind that any kind of modernization and "catching-up" in particular, involves risks and is costly. While solving old problems and conflicts, forced modernization generates new ones, complicated as well. Social structure, lifestyle, human mentality, value orientation are rapidly changing. In the framework of "catching-up" modernization, the state assumes full responsibility for the development and implementation of modernization [26]. As a result, there is danger of a complete removal of society, which in turn hinders the mobilization of internal resources necessary for modernization, creates resistance to innovation, and leads to aggravation of sociopolitical contradictions.

\section{REFERENCES}

[1] Derlug'yan G. Art Nouveau and modernizers. Ekspert [Expert], 2010, No. 1, spec. iss., p. 23. (In Russ.).

[2] Parsons T. The system of modern societies. Englewood Cliffs: Prentice-Hall, 1971. 152 p. [In Russ.: Parsons T. Sistema sovremennykhobshchestv. Moscow: Aspekt Press Publ., 1998. Pp. 240-241].

[3] Toffler A. The third wave. L.: Collins, 1980. 543 p. [In Russ.: Toffler A. Tret'yavolna. Moscow: AST Publ., 1999. P. 14].
[4] Suzdaleva T.R. Migratory processes in the context of geopolitics // VestnikTomskogogosudarstvennogouniversiteta-Filosofiyasotsiologiya-politologiya-Tomsk state university journal of philosophy sociology and political science. 2016. № 3 (36). P. 237 244. DOI: $10.17223 / 1998863 X / 35 / 25$.

[5] GraninYu.D. The West and the alternative model of modernization. Age of Globalization, 2017, no. 3(23), pp. 17-30 (In Russ.).

[6] Poberezhnikov I.V. Modernization in the history of Russia: trends and investigation problems. Ural Historical J., 2017, no. 4, pp. 36-45 (In Russ.).

[7] Suzdaleva T.R. Modernization as understood by scientists Modernization as a condition for the development of modern Russia: XI intern. scientific and practical conf. (Moscow, Russia, May 27th, 2011): Proc. Moscow: Moscow Economico-Statistical Inst. Publ., 2011. Pp. $42-46$ (In Russ.).

[8] Fedotova V.G. Modernization and culture. Moscow: ProgressTradition Publ., 2016. 334 p. (In Russ.).

[9] Gavrov S.N. Modernization in the name of the Empire. Socio-cultural aspects of modernization processes in Russia. Moscow: URSS, 2004. 349 p. (In Russ.).

[10] Lee Kuan Yew. The Singapore history. 1965-2000. From the Third world to the First one. 2nd ed. Moscow: MGIMO Univ. Publ., 2010. 657 p. (In Russ.).

[11] Komissarov I; Nekhamkin V. The Models of Historical Cognition: Current Status and Prospects of Development // IstoriyaElektronnyinauchno-obrazovatelnyuzhurnal. 2017. Vol. 8. Issue 2. DOI: $10.18254 / \mathrm{S} 0001779-5-1$

[12] Suzdaleva T.R. "Catching-up" modernization: domestic and foreign experience. Russia: trends and development prospects. Yearbook. No. 7. Pt. 1. Moscow, 2012. Pp. 151-155 (In Russ.)

[13] Suzdaleva T.R., Fedorov K.V. Modernization: foreign experience and lessons for Russia. Society - Language - Culture: problems of interaction in the XXI century: XV Intern. symp. "Unique phenomena and universal cultural values" (Moscow, 2013)]: Proc. Moscow, 2013. Pp. 19-21 (In Russ.).

[14] Fedorov K.V., Suzdaleva T.R., Davletshina N.V. Russia and the world in the second half of XX - beginning of XXI century: search for a model of development. Moscow: BMSTU Publ., 2013. Pp. 5451 (In Russ.)

[15] The world economy: global trends over 100 years. / Ed. by I.S Korolev. Moscow: Yurist Publ., 2003. Pp. 503-514 (In Russ.).

[16] Fedorov K.V., Suzdaleva T.R., Davletshina N.V. Russia and the world in the second half of XX - beginning of XXI century: search for a model of development. Moscow: BMSTU Publ., 2013. P. 53 (In Russ.).

[17] Gubanov N.I., Gubanov N.N. The role of mentality in the development of society: sociocultural hypothesis // Vestnikslavianskikh kultur-bulletin of slavic cultures-scientific and informational journal. 2017. Vol. 43. № 1. P. 38-51.

[18] Zemtsov B.N., Shubin A.V. Metamorphoses of Russian modernization. Svobodnaiamysl' (Free Thought), 2011, no. 2, p. 54 (In Russ.).

[19] The world economy: global trends over 100 years. / Ed. by I.S. Korolev. Moscow: Yurist Publ., 2003. P. 508 (In Russ.)

[20] Selishchev A.S., Selishchev N.A. The Chinese economy in the XXI century. Moscow a.o.: Piter Publ., 2004. Pp. 197-198 (In Russ.).

[21] Fedotova V.G. Globalization and modernization: a cultural factor. Knowledge. Understanding. Skill, 2017, no. 4, p. 62. DOI: 10.17805/zpu.2017.4.6 (In Russ.)

[22] Nekhamkin V.A. A counterfactual Challenge of the Past: Ways of Negotiation // Herald of the Russian Academy of Sciences. 2017. Vol 87. Issue 2. P. 191-198. DOI: 10.1134/S1019331617020046

[23] Ivlev Yu. V., IvlevV.Yu., Ivleva M.L. Logical-argumentative basics of educational culture // Proceedings of 4th International Conference on Education, Language, Art and Intercultural Communication (ICELAIC 2017)Part of the series ASSEHR. Moscow, Russia. Pp. $173-177$ 
[24] Zemtsov B.N. The specifics of the Russian reforms (a historical retrospective). Modernization as a condition for the development of modern Russia: XI intern. scientific and practical conf. (Moscow, Russia, May 27th, 2011): Proc. Moscow, 2011. P. 65 (In Russ.).

[25] Development strategy of the country 2018-2014. Available at: http://csr.ru/wp/con/tent/uploads/2017/09/Report/SF.pdf, accessed 9.05.2018 (In Russ.).

[26] Oseledchik M.B., IvlevV.Yu., Ivleva M.L. Knowledge as a nonequilibrium dynamic system // "Proceedings of the 2017 2nd International Conference on Contemporary Education, Social Sciences and Humanities". (ICCESSH 2017). Part of the series ASSEHR. Moscow, Russia. V/124. P.1-5. 